\title{
Analysis of Intestinal Mucosal Microbiome Changes before and after Chemoradiation in Locally Advanced Rectal Cancer Patients
}

\author{
Incheol Seo', Sung Uk Bae ${ }^{2 *}$, Shin Kim³ ${ }^{3}$ Woon Kyung Jeong ${ }^{2}$ and Seong Kyu Baek ${ }^{2}$ \\ 1Dasa Geriatric Hospital, Daegu, Korea \\ 2Department of Surgery, School of Medicine, Keimyung University and Dongsan Medical Center, Daegu, Korea \\ ${ }^{3}$ Department of Immunology, School of Medicine, Keimyung University, Daegu, Korea
}

\author{
Corresponding \\ Sung Uk Bae, M.D. \\ Department of Surgery, Keimyung University \\ School of Medicine 1095 Dalgubeol-daero, \\ Dalseo-gu, Daegu 42601, Korea \\ Phone : +82-53-258-4701 \\ Fax : +82-53-258-4701 \\ E-mail : sabiston0000@hanmail.net
}

Received : August 21, 2019

Revised : October 10, 2019

Accepted : October 15, 2019

No potential conflict of interest relevant to this article was reported.

Copyright (C 2019 Journal of Bacteriology and Virology

(1)This is an Open Access article distributed under the terms of the Creative Commons Attribution Non-Commercial License (http://creativecommons.org/ license/by-nc/3.0/)
Purpose: Dysbiosis of gut microbiota has been reported to participate in the pathogenesis of colorectal cancer, but changes in microbiota due to radiotherapy have not been studied. In this study, we tried to elucidate the changes in the microbiome in rectal cancer after chemoradiotherapy using RNA sequencing analysis.

Materials and methods: We included 11 pairs of human rectal cancer tissues before and after irradiation between August 2016 and December 2017 and performed RNA sequencing analysis. Mapped reads to human reference genomes were used for pair-wise transcriptome comparisons, and unmapped (non-human) reads were then mapped to bacterial marker genes using PathSeq.

Results: At microbiome level, interindividual variability of mucosal microbiota was greater than the change in microbial composition during radiotherapy. This indicates that rapid homeostatic recovery of the mucosal microbial composition takes place short after radiotherapy. At single microbe level, Prevotella and Fusobacterium, which were identified as important causative microbes of the initiation and progression of rectal cancer were decreased by radiotherapy. Moreover, changes in Prevotella were associated with changes in the human transcriptome of rectal cancer. We also found that there was a gene cluster that increased and decreased in association with changes in microbial composition by chemoradiation.

Conclusion: This study revealed changes in tumor-associated microbial community by irradiation in rectal cancer. These findings can be used to develop a new treatment strategy of neoadjuvant therapy for locally advanced rectal cancer by overcoming radio-resistance or facilitating radio-sensitivity.

Key Words: Microbiome, Rectal cancer, Radiotherapy

\section{INTRODUCTION}

직장암의 치료에 있어 수술 전 화학방사선요법 (chemoradiation therapy, CRT)은 종양 의 크기를 줄이고 (downsizing), 병기를 하강시켜 (downstaging) 직장암의 근치적 절 제율을 높여 국소재발율을 낮추고 궁극적으로는 생존율의 향상에 기여하는 것으로 밝 혀졌다 (1-3). 수술 전 항암방사선 치료에 대한 종양의 반응은 완전 관해부터 무반응까 지 다양하게 보고되고 있는데, $10-30 \%$ 에서는 종양이 완전히 사라지는 병리학적 완전 관해 (pathologic complete response)가 나타나는 반면, $20-25 \%$ 의 환자는 전혀 반응 을 나타내지 않든가 오히려 치료 기간 동안 병이 진행되는 경우도 있다 (4). 
방사선 치료는 직접적으로 종양에 방사선을 가함으로써, 종양의 크기를 줄이고, 종양의 국소 치료 효과를 높일 뿐만 아니라, 종양 세포에서 항원제시세포 (antigen-presenting cells, APC)로의 종양항원 누출을 촉진시켜 종양 특이 T 세포를 활성화시킨다. 그리 고 종양 미세환경 (tumor microenvironment)의 전 염증 조절인자 (pro-inflammatory modifiers)로 작용하는 신호들을 유도함으 로써 항종양 면역성을 나타내는 것으로 보고되었다 $(5,6)$. 최근에는 종양-면역학 분야가 발전함에 따라 방사선 치료 후에 다양한 면역학적 변화가 일어나는 것을 근거로 방사선 치료와 면역항암제의 병합요법에 대해서도 활발한 연구가 진행되고 있다 (7).

인체 마이크로바이옴 (microbiome)은 인간의 몸 안팎에 서식하고 있는 미생물들과 유전정보 전체를 말하는 것으로, 우리 몸에는 매우 많은 미생물이 서식하고 있으며 인간의 건강과 질병에 미치는 영향이 매우 큰 것으로 알려져 있다. 특히, 장 내 마이크로바 이옴은 인간의 상피 장벽에 존재하면서 국소적 혹은 전신적인 대사기능, 염증반응, 후천성 면역에 영향을 미치고, 이는 종양의 발 생, 진행, 항종양 치료의 반응에 영향을 미치는 것으로 보고되었다 (8-10). 최근 동물 모델에서 방사선 조사가 장내 마이크로바이 옴에 미치는 영향에 대해서는 보고되었으나, 인체의 직장암 인접 점막에서의 방사선 치료가 마이크로바이옴의 변화에 주는 영향 에 대해서는 보고된 바가 없다. 이 연구에서는 진행성 직장암 환자의 CRT 전후 직장암 점막의 마이크로바이옴을 분석하고 방사선 치료로 인한 인체의 전사체 변화와 마이크로바이옴의 변화에 대한 통합분석 (integration analysis)을 실시하였다.

\section{MATERIALS AND METHODS}

\section{연구 대상자 선정 및 검체 수집}

이 연구는 계명대학교 동산병원 의학연구윤리심의위원회의 승인을 받아 진행되었다 (심의번호: 2016-08-020). 2016년 8월부터 2017년 12월까지 계명대학교 동산의료원에서 수술 전 신보조 동시 (neoadjuvant concurrent) CRT를 시행 받은 2기 3기의 (T3 또는 T4 또는 림프절 양성) 직장 선암 (rectal adenocarcinoma) 환자 54명을 연구 대상자로 선정하였다. 그 중 가족성 선종성 용종증이나 유전성 비용종증 대장암 환자, 동반 암이 있거나 이전에 악성 종양이 있었던 환자, CRT 도중 전이암이 발생한 환자, 절제 수술을 거부한 환자, 추적 관찰 도중 이탈한 환자를 제외하고 최종적으로 11명의 환자를 최종 연구 대상자로 선정하였다. 11 명의 환자에서 CRT 전 S상 결장경을 통해 얻은 직장암 점막 생검 검체와 CRT 후 원발 종양의 외과적 절제술을 통해 얻은 검 체를 각각 획득하여 총 11쌍의 CRT 전후 직장암에 대한 mRNA 염기 서열 분석을 시행하였다. 이 환자들은 fluorouracil 기반의 화학요법과 $50.4 \mathrm{~Gy}$ 의 방사선 치료를 5주기에 걸쳐 받는 전통적인 장기간 신보조 (conventional long-course neoadjuvant) CRT 를 시행 받았다. 모든 환자에서 복부-골반 및 흉부 컴퓨터 단층 스캔, 직장 자기 공명 영상, 대장 내시경 검사와 생검 및 양전자 방출 단층 촬영 스캔이 시행되었다. 간막 전절제 (total mesorectal excision)는 마지막 CRT의 6-8주 이내에 시행되었다. 연구 대 상 환자의 연령, 성별, 체질량 지수, 수술 전 TNM 병기, 조직학적 소견, 종양 발아 (tumor budding), 림프관 침윤, 신경계 침윤, 림프절외 침범, 현미부수체 불안정성 (microsatellite instability), KRAS 돌연변이, BRAF 돌변변이, CRT 후 종양반응 (tumor regression grade) 여부는 Table 1과 같다.

Table 1. Patient characteristics

\begin{tabular}{|c|c|c|c|c|c|c|c|c|c|c|c|c|c|}
\hline $\mathrm{ID}^{a}$ & Age & Sex & $\mathrm{BMI}^{b}$ & Diff $^{c}$ & $\mathrm{Bud}^{d}$ & $\mathrm{PNI}^{e}$ & $\mathrm{ETD}^{f}$ & $\mathrm{MSI}^{g}$ & KRAS $^{h}$ & BRAF $^{i}$ & $\mathrm{TRG}^{j}$ & $\mathrm{pT}^{k}$ & $\mathrm{pN}^{\prime}$ \\
\hline 1 & 68 & $M$ & 20.3 & 1 & $Y$ & $\mathrm{~N}$ & $\mathrm{~N}$ & $\mathrm{~L}$ & $\mathrm{~N}$ & $\mathrm{~N}$ & NR & 3 & 0 \\
\hline 2 & 82 & M & 19.1 & 1 & Y & $\mathrm{N}$ & $\mathrm{Y}$ & $\mathrm{L}$ & $\mathrm{N}$ & $\mathrm{N}$ & NR & 3 & 2 \\
\hline 3 & 48 & M & 23.7 & 1 & $\mathrm{~N}$ & $\mathrm{~N}$ & $\mathrm{~N}$ & $\mathrm{~L}$ & $\mathrm{~N}$ & $\mathrm{~N}$ & NR & 3 & 0 \\
\hline 4 & 72 & $\mathrm{M}$ & 22.9 & 1 & $\mathrm{~N}$ & $\mathrm{~N}$ & Y & $\mathrm{L}$ & $\mathrm{N}$ & $\mathrm{N}$ & NR & 3 & 2 \\
\hline 5 & 66 & $\mathrm{M}$ & 20.9 & 1 & $\mathrm{~N}$ & $\mathrm{~N}$ & $\mathrm{~N}$ & $\mathrm{~L}$ & $\mathrm{Y}$ & $\mathrm{N}$ & NR & 3 & 0 \\
\hline 6 & 69 & $\mathrm{M}$ & 23.9 & 1 & $\mathrm{~N}$ & $\mathrm{~N}$ & $\mathrm{~N}$ & $\mathrm{~L}$ & $\mathrm{Y}$ & $\mathrm{N}$ & NR & 1 & 0 \\
\hline 7 & 76 & $\mathrm{M}$ & 21.3 & 1 & $\mathrm{~N}$ & $\mathrm{~N}$ & $\mathrm{~N}$ & $\mathrm{~L}$ & $\mathrm{~N}$ & $\mathrm{~N}$ & NR & 3 & 1 \\
\hline 8 & 47 & $\mathrm{M}$ & 26.3 & 1 & $\mathrm{~N}$ & $\mathrm{~N}$ & $\mathrm{~N}$ & $\mathrm{~L}$ & $\mathrm{~N}$ & $\mathrm{~N}$ & NR & 1 & 0 \\
\hline 10 & 52 & $\mathrm{M}$ & 26.5 & 1 & $\mathrm{~N}$ & $\mathrm{~N}$ & $\mathrm{~N}$ & $\mathrm{~L}$ & $\mathrm{~N}$ & $\mathrm{~N}$ & NR & 2 & 0 \\
\hline 12 & 62 & $\mathrm{M}$ & 25.9 & 2 & $\mathrm{~N}$ & $\mathrm{~N}$ & $\mathrm{~N}$ & $\mathrm{~L}$ & $\mathrm{Y}$ & $\mathrm{N}$ & $\mathrm{R}$ & 1 & 1 \\
\hline 14 & 55 & M & 18.9 & 2 & $\mathrm{~N}$ & $\mathrm{~N}$ & $\mathrm{~N}$ & $\mathrm{H}$ & $\mathrm{N}$ & $\mathrm{N}$ & $\mathrm{R}$ & 2 & 0 \\
\hline
\end{tabular}

$\mathrm{ID}^{a}$ : patient identification number, $\mathrm{BMI}^{b}:$ body mass index, Diff $^{c}:$ differentiation $(1=$ well and moderately differentiated, $2=$ poorly differentiated), Bud ${ }^{d}$ : presence of tumor budding, PNI ${ }^{e}$ : presence of perineural invasion, ETD $f$ : presence of extranodal tumor deposit, $\mathrm{MSI}^{g}$ : microsatellite instability $\left(\mathrm{H}\right.$ : high, $\mathrm{L}$ : low), KRAS $\mathrm{S}^{h}$ : presence of KRAS exon 2 mutation, BRAF: presence of $\mathrm{BRAF}$ mutation, $\mathrm{TRG}^{j}$ : Mandard tumor regression grade $\left(\mathrm{NR}=\right.$ non-responder, $\mathrm{R}=$ responder), $\mathrm{pT}^{k}$ : primary tumor categories, $\mathrm{pN}^{\prime}$ : regional lymph node categories. 
RNA 추출, 라이브러리 준비, 염기 서열 분석

TRIzolß RNA Isolation Reagents (Life technologies)를 이용하여 11쌍의 직장 선암 검체로부터 RNA를 추출했다. 추출된 RNA의 양과 품질은 Agilent 2100 bioanalyzer RNA kit (Agilent)를 이용하여 평가했다. 추출된 RNA는 Illumina TruSeq Stranded mRNA Sample Preparation kit (lllumina)를 사용하여 제조사의 권장 사항을 준수하여 라이브러리로 준비되었다. 라이브러리의 품질과 크 기는 Agilent 2100 bioanalyzer RNA kit로 평가했다. 모든 라이브러리는 CFX96 Real Time System (Bio-Rad)을 사용하여 qPCR로 정량화 한 후 NextSeq500 sequencer (Illumina)에서 76 bp의 paired-end reads로 염기 서열이 분석되었다.

\section{RNA 염기 서열 분석 자료에서 세균 군집 분석}

원시 염기 서열의 품질 관리를 위해 Trimmomatic 소프트웨어를 사용하여 낮은 품질의 염기 서열과 어댑터 서열을 제거했다 (11). 그 결과 염기 서열의 길이가 $38 \mathrm{bp}$ 이하가 된 경우는 후속 분석에서 제외했다. 품질 관리가 완료된 염기 서열은 STAR aligner를 사용하여 hg38 인간 유전체에 정렬 (mapping) 되었다 (12). hg38 참조 서열에 정렬되지 않아 인간으로부터 유래되지 않은 것으로 추측되는 염기 서열은 PathSeq을 이용하여 세균의 표지 (marker) 유전자에 대해 다시 정렬된 후 구성 비율의 표준 화 점수로 변환되었다 (13). 각 단계 분석에서 포함되거나 제외된 reads의 수는 Table 2와 같다. PathSeq 분석으로 얻어진 세균 군집 구성 비율의 표준화 점수는 분류학적 계급 (taxonomic rank)에 따라 문 (phylum), 강 (class), 목 (order), 과 (family)로 각 각 분리되어 분석되었다.

Table 2. Read count statistics

\begin{tabular}{|c|c|c|c|c|}
\hline $\mathrm{ID}^{a}$ & $\operatorname{Raw}^{b}$ & Trimmed $^{c}$ & STAR hg38 mapped $^{d}$ & PathSeq mapped $^{e}$ \\
\hline 1-PRE & $36,117,126$ & $33,467,266(92.66)$ & $32,728,484(97.79)$ & $3,823(0.52)$ \\
\hline 1-POST & $40,603,836$ & $37,531,060(92.43)$ & $36,479,616(97.20)$ & $11,091(1.05)$ \\
\hline 2-PRE & $33,651,376$ & $31,085,808$ (92.38) & $30,357,966(97.66)$ & $1,375(0.19)$ \\
\hline 2-POST & $37,676,934$ & $35,089,930(93.13)$ & $34,145,894(97.31)$ & $2,167(0.23)$ \\
\hline 3-PRE & $33,814,488$ & $31,352,044(92.72)$ & $30,667,390(97.82)$ & $743(0.11)$ \\
\hline 3-POST & $41,076,234$ & $38,043,256(92.62)$ & $37,131,382(97.60)$ & $1,829(0.20)$ \\
\hline 4-PRE & $37,723,686$ & $35,039,152(92.88)$ & $34,351,546(98.04)$ & $558(0.08)$ \\
\hline 4-POST & $38,123,926$ & $35,325,968$ (92.66) & $34,509,702(97.69)$ & $535(0.07)$ \\
\hline 5-PRE & $34,610,764$ & $32,432,364(93.71)$ & $31,827,396(98.13)$ & $368(0.06)$ \\
\hline 5-POST & $35,607,408$ & $33,002,822$ (92.69) & $32,001,644(96.97)$ & $400(0.04)$ \\
\hline 6-PRE & $36,922,016$ & $33,943,450$ (91.93) & $33,219,332(97.87)$ & $1,759(0.24)$ \\
\hline 6-POST & $39,258,648$ & $36,316,266(92.51)$ & $35,422,606(97.54)$ & $913(0.10)$ \\
\hline 7-PRE & $35,947,852$ & $32,041,046(89.13)$ & $31,262,064(97.57)$ & $866(0.11)$ \\
\hline 7-POST & $37,071,050$ & $34,198,736(92.25)$ & $33,322,702(97.44)$ & $2,292(0.26)$ \\
\hline 8-PRE & $35,584,204$ & $32,114,960(90.25)$ & $31,413,688(97.82)$ & $711(0.10)$ \\
\hline 8-POST & $35,396,596$ & $32,669,576(92.30)$ & $31,607,626(96.75)$ & $602(0.06)$ \\
\hline 10-PRE & $35,992,904$ & $33,461,710(92.97)$ & $32,780,456(97.96)$ & $107(0.02)$ \\
\hline 10-POST & $38,726,232$ & $35,770,152(92.37)$ & $34,908,248(97.59)$ & $456(0.05)$ \\
\hline 12-PRE & $37,282,074$ & $34,354,054(92.15)$ & $33,507,390(97.54)$ & $3,779(0.45)$ \\
\hline 12-POST & $33,343,146$ & $27,512,050(82.51)$ & $26,196,644(95.22)$ & $695(0.05)$ \\
\hline 14-PRE & $37,105,578$ & $32,919,990(88.72)$ & $31,518,358(95.74)$ & $40,519(2.89)$ \\
\hline 14-POST & $43,542,422$ & $41,159,148(94.53)$ & $40,441,644(98.26)$ & $33,475(4.67)$ \\
\hline
\end{tabular}

The numbers in parentheses, excluding the "PathSeq mapped" column, represent the percentage of read count in the previous step. The number in parentheses in the "PathSeq mapped" column is the percentage of non-human read counts which unmapped to hg38. ID : sample identification number (The number before hyphen indicates patient identification number. "PRE" and "POST" represent samples before and after chemoradiation therapy.), Raw": raw read counts, Trimmed": read counts after quality control. STAR hg38 mapped ${ }^{d}$ : read counts mapped to hg38 human reference genome using STAR aligner. PathSeq mapped ${ }^{e}$ : read counts mapped to bacterial marker genes using PathSeq. 


\section{항암화학방사선요법 전후 세균 군집의 변화 분석}

11 쌍의 CRT 전후 검체의 세균 군집 구성을 비교하기 위해서 PathSeq 분석에서 얻은 각 분류학적 계급에 따른 운영분류단위 (operational taxonomic unit, OTU)의 표준화점수로부터 계산된 세균의 상대 존재량 (relative abundance)을 이용해서 skyline 도표가 작성되었으며 개인별 세균 군집의 변화를 확인하기 위해서 막대 도표가 각각 작성되었다 (Fig. 1). CRT 전후 군 간의 세균 군집 구성의 차이를 확인하기 위해서 표준화 점수는 weighted UniFrac, generalized UniFrac, Bray-Curtis 거리의 세가지 형태의 행렬로 각각 변환되었다. 이 후 각각의 행렬에 대해 다변량 분산분석 (permutational multivariate analysis of variance, PERMANOVA)으로 1000 번의 permutation 검정이 시행되었다 (Table 3). 검체 간의 세균 군집의 유사도를 확인하기 위해서 주 성분분석이 시행되었다 (Fig. 2)

\section{A. Phylum}
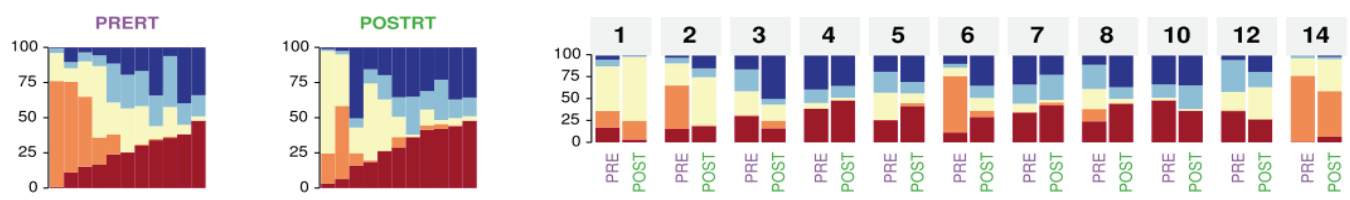

\section{B. Class}
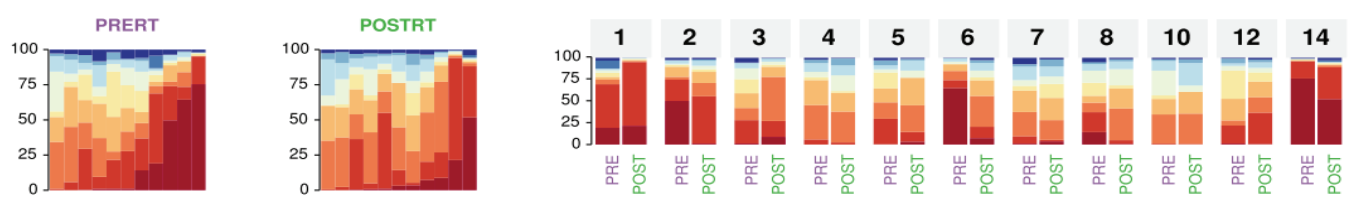

\section{Order}
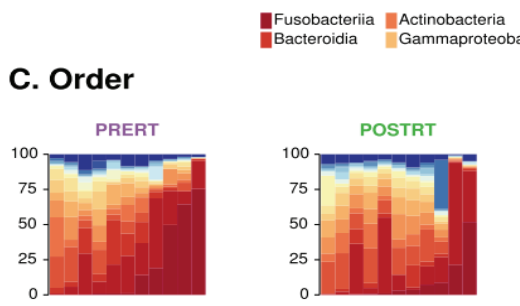

Clostridia

Bacilli Deltaproteobacteria
55 other classes
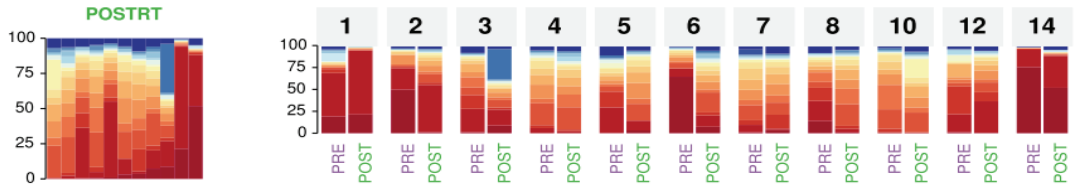

\section{Family}
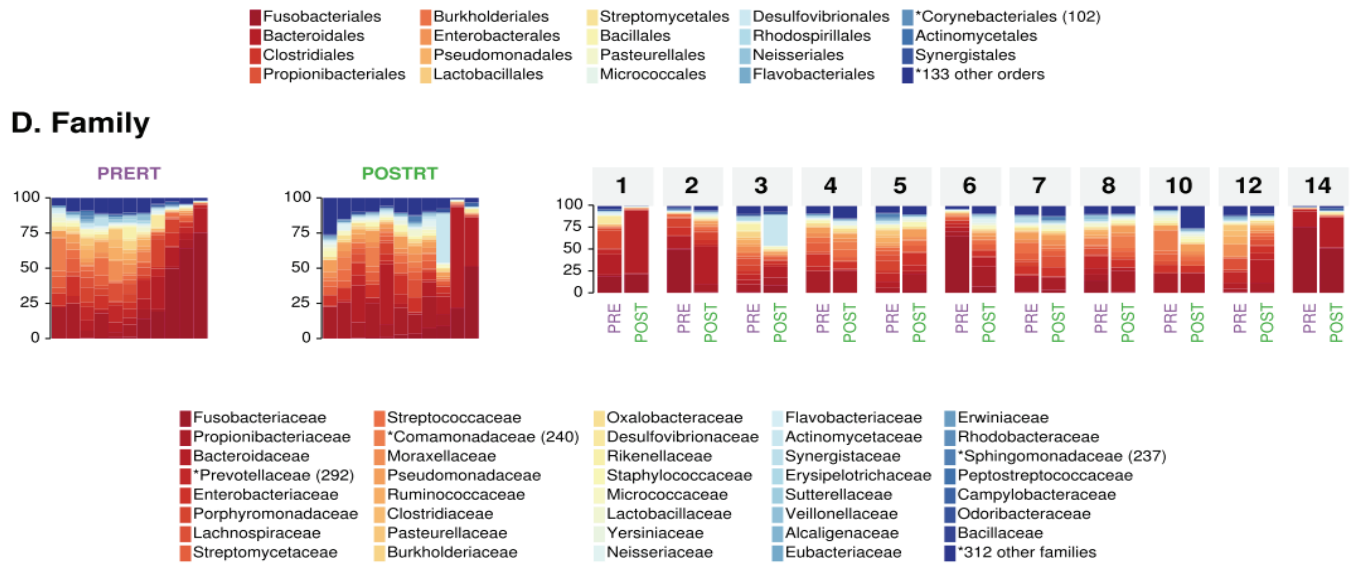

Fig. 1. Microbial composition before and after chemoradiation in rectal cancer patients. The relative abundance of OTU is shown for each taxonomic rank. The paired bar plots on the right show the microbial composition before and after chemoradiation in the same patients. The numbers on the bar plot represent the patient identification numbers. The skyline plots on the left show the bar plot in ascending order based on the most abundant OTU. The $y$-axis of both charts indicates the relative abundance (\%). "PRE" and "PRERT" represent samples before chemoradiation therapy. "POST" and "POSTRT" represent samples after chemoradiation therapy. OTUs that differ in ANCOM analysis are marked with an asterisk and the W-statistics are shown in parentheses. (A) Phylum (B) Class (C) Order and (D) Family. 
Table 3. PERMANOVA results testing the effect of chemoradiation on microbial composition

\begin{tabular}{cccc}
\hline \multirow{2}{*}{ Taxonomic rank } & & PERMANOVA ${ }^{a}$ p-value & Bray-Curtis \\
\cline { 2 - 4 } & Weighted UniFrac & Generalized UniFrac & 0.4386 \\
Phylum & 0.3976 & 0.3796 & 0.3736 \\
Class & 0.3177 & 0.3616 & 0.3666 \\
Order & 0.3367 & 0.3836 & 0.2348 \\
Family & 0.2777 & 0.2977 & \\
\hline
\end{tabular}

Three distance metrics were used to test the differences in microbial composition before and after chemoradiation therapy in rectal adenocarcinoma patients. PERMANOVA ${ }^{a}$ : permutational multivariate analysis of variance.

\section{A. Phylum}

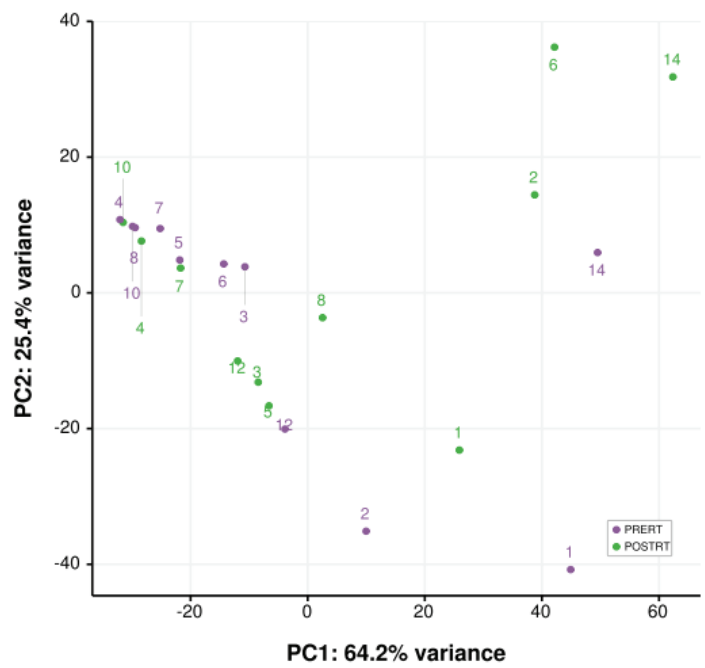

C. Order

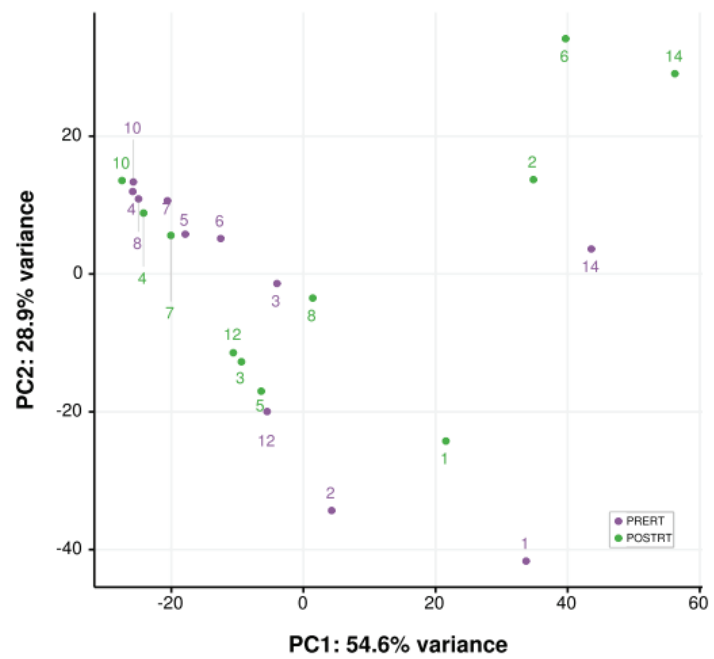

\section{B. Class}

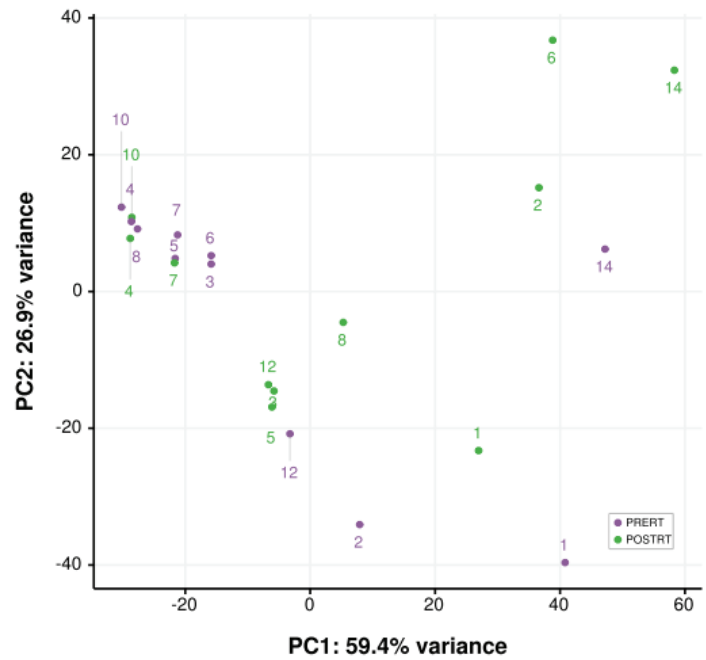

D. Family

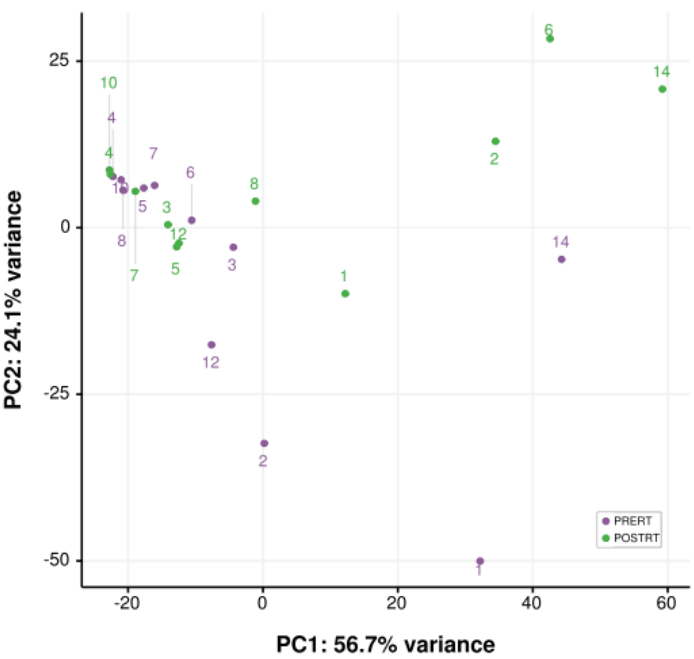

Fig. 2. Principal component analysis of the microbiota before and after chemoradiation in rectal cancer patients. The numbers represent the patient identification numbers. "PRERT" and "POSTRT" represent samples before and after chemoradiation therapy, respectively. (A) Phylum (B) Class (C) Order (D) Family. 
Table 4. ANCOM analysis between before and after chemoradiotherapy

\begin{tabular}{|c|c|c|c|c|c|c|c|}
\hline Taxonomic rank & OTU names & $\mathrm{W}^{a}$ & $N_{\text {feat }}^{b}$ & D_0.9 $9^{C}$ & D_0.8 $8^{d}$ & D_0.7 $7^{e}$ & D_0.6 ${ }^{f}$ \\
\hline Order & Rhizobiales & 110 & 152 & $\mathrm{~N}$ & Y & Y & Y \\
\hline Order & Corynebacteriales & 102 & 152 & $\mathrm{~N}$ & $\mathrm{~N}$ & Y & Y \\
\hline Order & Xanthomonadales & 102 & 152 & $\mathrm{~N}$ & $\mathrm{~N}$ & Y & Y \\
\hline Order & Sphingomonadales & 97 & 152 & $\mathrm{~N}$ & $\mathrm{~N}$ & Y & Y \\
\hline Order & Pseudonocardiales & 94 & 152 & $\mathrm{~N}$ & $\mathrm{~N}$ & Y & Y \\
\hline Family & Prevotellaceae & 292 & 351 & Y & Y & Y & Y \\
\hline Family & Comamonadaceae & 240 & 351 & $\mathrm{~N}$ & $\mathrm{~N}$ & Y & Y \\
\hline Family & Sphingomonadaceae & 237 & 351 & $\mathrm{~N}$ & $\mathrm{~N}$ & Y & Y \\
\hline Family & Xanthomonadaceae & 236 & 351 & $\mathrm{~N}$ & $\mathrm{~N}$ & Y & Y \\
\hline Family & Pseudonocardiaceae & 230 & 351 & $\mathrm{~N}$ & $\mathrm{~N}$ & Y & Y \\
\hline Family & Leuconostocaceae & 166 & 351 & $\mathrm{~N}$ & $\mathrm{~N}$ & $\mathrm{~N}$ & $\mathrm{~N}$ \\
\hline Family & Dermabacteraceae & 148 & 351 & $\mathrm{~N}$ & $\mathrm{~N}$ & $\mathrm{~N}$ & $\mathrm{~N}$ \\
\hline Family & Sanguibacteraceae & 124 & 351 & $\mathrm{~N}$ & $\mathrm{~N}$ & $\mathrm{~N}$ & $\mathrm{~N}$ \\
\hline Family & Aurantimonadaceae & 123 & 351 & $\mathrm{~N}$ & $\mathrm{~N}$ & $\mathrm{~N}$ & $\mathrm{~N}$ \\
\hline Family & Sporomusaceae & 122 & 351 & $\mathrm{~N}$ & $\mathrm{~N}$ & $\mathrm{~N}$ & $\mathrm{~N}$ \\
\hline Family & Tolypothrichaceae & 70 & 351 & $\mathrm{~N}$ & $\mathrm{~N}$ & $\mathrm{~N}$ & $\mathrm{~N}$ \\
\hline
\end{tabular}

ANCOM: Analysis of composition of microbiomes, $\mathrm{W}^{a}$ : ANCOM W-statistics, $\mathrm{N}_{\text {feat }}{ }^{b}$ : Total number of OTUs detected within the same taxonomic rank, D_0.9 ${ }^{\mathcal{C}} \sim$ D_0.6 $6^{f}$. ANCOM significance with cut-offs from 0.9 to 0.6 .

\section{항암화학방사선요법 전후로 변화된 세균 탐색}

CRT 전후로 유의하게 변화된 OTU을 탐색하기 위해서 분류학적 계급에 따라 analysis of composition of microbiomes (ANCOM) 가 각각 시행되었다 (Table 4) (14). ANCOM의 유의성 검정 기준 0.9를 충족하는 세균 분류군인 Prevotellaceae의 CRT 전후의 상대 존재량을 Fig. 3A에서 상자 도표로 나타냈다.

Table 5. Top 10 genes showing the strongest positive correlation with the abundance of Prevotellaceae

\begin{tabular}{clc}
\hline Gene symbol & \multicolumn{1}{c}{ Gene name } & Pearson's r \\
\hline TRAFD1 & TRAF-type zinc finger domain containing 1 & 0.917 \\
IFIT1 & Interferon induced protein with tetratricopeptide repeats 1 & 0.914 \\
ADAM22 & ADAM metallopeptidase domain 22 & 0.908 \\
CGRRF1 & Cell growth regulator with ring finger domain 1 & 0.908 \\
ACTR6 & ARP6 actin-related protein 6 homolog & 0.902 \\
CHD9 & Chromodomain helicase DNA binding protein 9 & 0.901 \\
ASB8 & Ankyrin repeat and SOCS box containing 8 & 0.900 \\
ZFP30 & ZFP30 zinc finger protein & 0.890 \\
MFAP3L & Microfibrillar associated protein 3 like & 0.882 \\
ELAC1 & elaC ribonuclease Z 1 & 0.882 \\
\hline
\end{tabular}


A

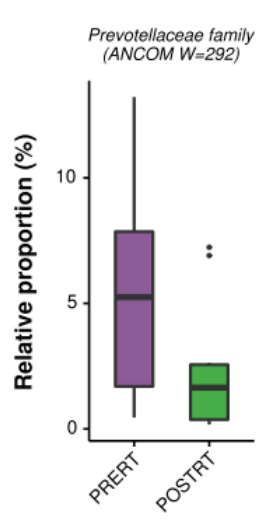

B

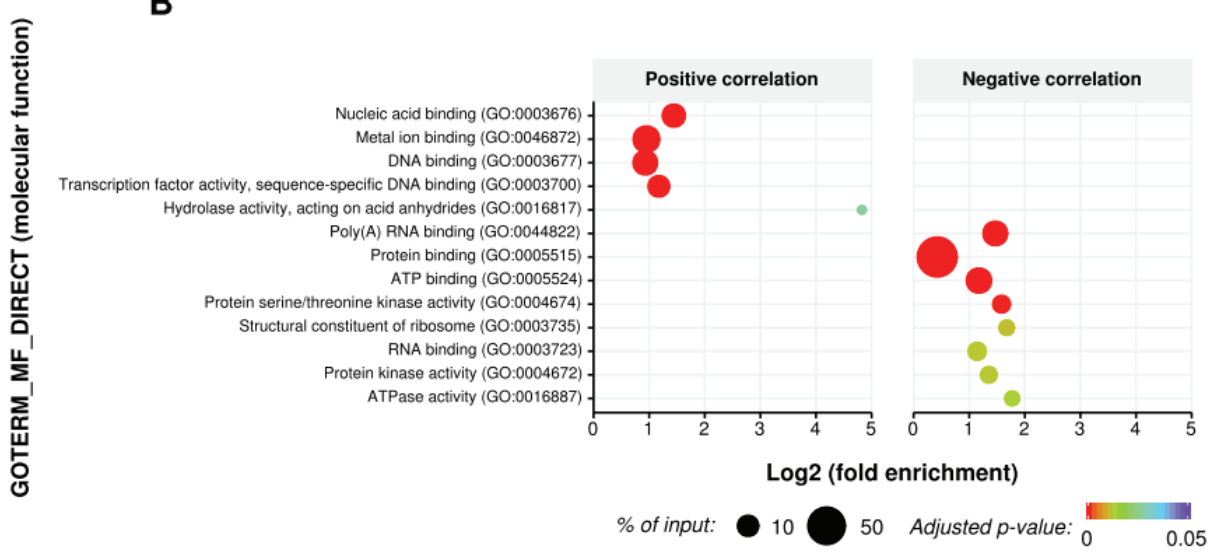

Fig. 3. Changes in the abundance of Prevotellaceae family after chemoradiation and concomitant changes in the human transcriptome. (A) Box plot shows the relative abundance of Prevotellaceae before and after chemoradiotherapy. "PRERT" and "POSTRT" represent samples before and after chemoradiation therapy, respectively. (B) Bubble chart shows the functional annotation of host gene expression highly correlated with changes in relative abundance of Prevotellaceae before and after chemoradiotherapy. Gene-Enrichment and Functional Annotation Analysis was performed using DAVID. The y-axis represents the functional term defined in GOTERM MF_DIRECT. The numbers in parentheses are the identification numbers of the Gene Ontology. Fold enrichment, ratio of the number of genes involved the function term to the total number of inputs genes, and $\mathrm{p}$-value are represented by $\mathrm{x}$-axis, bubble size, and bubble color, respectively.

\section{항암화학방사선요법 전후의 인간 유전체 발현 변화와 Prevotellaceae의 변화의 통합분석}

CRT 전후의 인간 유전체 발현 변화를 탐색하기 위해서 STAR aligner로 hg38 인간 유전체 참조 서열에 정렬된 reads를 계수 (counting)하였다. 계수 결과는 DESeq2 소프트웨어를 이용해 표준화되었다 (15). 이후 표준화된 계수 값에서 각 환자의 CRT 전 후의 개별 유전자의 발현량의 배수 차이 (fold change)를 계산했다. 개별 유전자에 대한 11쌍의 발현량의 배수 차이는 밑이 2인 로그로 치환되었다. 다시 각 환자의 CRT 전후의 Prevotellaceae의 상대 존재량의 배수 차이를 구하고 밑이 2인 로그로 치환하여 11 개의 값을 얻었다. 이후 각 유전자의 로그 치환된 발현량의 배수 차이 값 11 개와 Prevotellaceae의 로그 치환된 배수 차이 값 11 개 사이의 상관분석을 시행하여 피어슨 상관계수 (Pearson correlation coefficient, r)를 얻었다. 상관분석 결과 Prevotellaceae 의 상대 존재량 변화와 발현량에서 가장 뚜렷한 양 또는 음의 상관관계를 보인 인간 유전자 상위 10 개는 각각 Table 5와 6 에 나 타냈다. 양 또는 음의 상관관계가 높은 인간 유전자를 순서대로 500 개씩 추출하여 DAVID를 이용하여 기능에 대한 주석을 부여 하였고 그 결과를 버블 도표로 시각화 했다 (Fig. 3B) (16).

Table 6. Top 10 genes showing the strongest negative correlation with the abundance of Prevotellaceae

\begin{tabular}{clc}
\hline Gene symbol & \multicolumn{1}{c}{ Gene name } & Pearson's r \\
\hline NSMF & NMDA receptor synaptonuclear signaling and neuronal migration factor & -0.940 \\
NPIPB11 & Nuclear pore complex interacting protein family member B11 & -0.937 \\
LRP5L & LDL receptor related protein 5 like & -0.933 \\
RANGAP1 & Ran GTPase activating protein 1 & -0.925 \\
PASK & PAS domain containing serine/threonine kinase & -0.908 \\
CDK10 & Cyclin dependent kinase 10 & -0.900 \\
HPCAL1 & Hippocalcin like 1 & -0.896 \\
NBEAL2 & Neurobeachin like 2 & -0.894 \\
ABCF3 & ATP binding cassette subfamily F member 3 & -0.884 \\
RPL12 & Ribosomal protein L12 & -0.882 \\
\hline
\end{tabular}


통계분석

모든 통계 분석은 R에서 수행되었다 (17). 도표는 R에서 ggplot2 패키지를 사용하여 작성되었다 (18).

\section{RESULTS}

\section{RNA 염기 서열 분석 자료에서 세균 군집 분석}

11 쌍의 직장 선암 검체의 염기 서열을 분석하여 각 검체로부터 3 천 3 백만 4천 3 백만개의 reads의 원시 RNA 염기 서열 분석 자 료를 획득했다 (Table 2). 염기 서열 분석에 사용된 어댑터 서열과 품질이 낮은 염기쌍을 제외하는 과정을 통해서 원시자료의 $82.51 ~ 94.53 \%$ 에 해당하는 reads를 선별하였다. 다음으로 RNA 염기 서열로부터 미생물의 염기 서열만을 추출하기 위해서 품질 관리를 마친 reads를 hg38 인간 유전체 참조 서열에 정렬하여 $95.22 ~ 98.26 \%$ 의 reads를 각각 제거했다. 인간 참조 서열에 정 렬되지 않은 인간 이외로부터 유래한 $1.74 \sim 4.78 \%$ 의 reads는 PathSeq 프로그램을 통해 미생물의 표지 유전자에 정렬되었다. 그 결과 인간 이외로부터 유래한 reads들 중 0.02 4.67\%의 reads가 PathSeq에 의해 정렬되었다. PathSeg에 의해 미생물 표지 유 전자에 정렬된 reads 수는 CRT 전과 후 사이에 유사성을 갖기 보다는 10번 환자의 CRT 전후 (Table 2의 10-PRE와 10-POST), 14번 환자 (14-PRE와 14-POST)에서 잘 나타난 것처럼 개인안에 유사성을 띄고 있었다.

항암화학방사선요법 전후의 전체 세균 군집 변화 분석

PathSeq 분석을 통해 얻은 미생물의 군집 정보에서 세균만을 분류학적 계급에 따라 문, 강, 목, 과로 추출하여 각 OTU의 CRT 전후 상대 존재량을 비교한 것은 Fig. 1A D의 왼쪽 skyline 도표와 같다. CRT 전후의 미생물 군집에 전체적인 차이가 존재하는지 검증하기 위해서 PathSeq 결과의 각 OTU의 표준화 점수를 세가지 종류의 거리 행렬로 변환한 후 PERMANOVA를 시행한 결과 CRT 전과 후 사이에 미생물 전체 군집 단위에서는 통계적으로 유의한 차이가 관찰되지 않았다 (Table 3). 주성분분석에서 같은 환자안에서는 CRT 전후로 세균 군집의 전체적인 변화가 크지 않다는 것을 확인할 수 있었다 (Fig. 2).

항암화학방사선요법 전후의 개별 세균 변화 분석

Fig. 1의 skyline 도표에서 CRT 전후로 세부적인 OTU의 변화를 확인했을 때 네가지 분류학적 계급의 분석 모두에서 CRT 후에 fusobacteria가 감소하는 것을 확인할 수 있었다 (Fig. 1). 나머지 OTU에서는 눈에 띄는 변화는 찾을 수 없었다. 미생물 군집의 변화를 연구 대상자마다 CRT 전후로 비교했을 때에는 문 수준의 분석에서 2번과 6 번 환자에서 fusobacteria의 감소를 확인할 수 있었다 (Fig. 1A, 오른쪽 막대 도표). CRT 전후로 통계적으로 유의한 변화를 보인 OTU를 확인하기 위해서 시행한 ANCOM 분석 결과는 Table 4와 같다. 문과 강 수준에서는 통계적으로 유의하게 차이나는 OTU를 찾을 수 없었고 목 수준에서는 Rhizobiales가 ANCOM 유의성 기준 0.8 을 만족하였으며 그 외 4 개의 OTU에서 ANCOM의 0.7 의 기준에서 통계적 유의성을 보였다. 과 수준에서는 Prevotellaceae가 ANCOM 유의성 기준 0.9를 만족했으며 그 외 4개의 OTU가 0.7의 유의성을 만족하였고 6개 OTU는 ANCOM 통계량인 W값을 가졌지만 유의성 기준 0.6 을 만족하지 못했다. ANCOM 분석에서 가장 유의한 변화로 확인된 Prevotellaceae과는 CRT 후에 상대 존재량이 감소함을 확인할 수 있었다 (Fig. 3A).

\section{항암화학방사선요법 전후의 인간 유전체 발현 변화와 Prevotellaceae과의 변화의 통합분석}

11쌍의 직장 선암 검체로부터 확인된 CRT 전후의 Prevotellaceae과의 변화량과 높은 상관관계를 갖는 인간 유전자에 대한 기능 적 분류는 Fig. $3 \mathrm{~B}$ 와 같다. 양의 상관관계를 갖는 인간 유전자들은 핵산이나 DNA 결합과 관련되어 있는 반면 음의 상관관계를 갖는 인간 유전자는 RNA, 단백질, ATP와의 결합에 관련되어 있어 구분되는 특성이 확인되었다 (Table 5, 6).

\section{DISCUSSION}

장내 미생물이 소화기계 종양의 발생과 진행에 미치는 영향은 이미 잘 알려져 있다 (8-10). 장내 마이크로바이옴을 가진 생쥐가 
무균 생쥐보다 소장 선종 발생이 더 많다는 것이 보고되었으며 (19), 장내에서 Escherichia co/와 Bacteroides fragilis는 대장직장 암 (colorectal cancer, $\mathrm{CRC}$ )의 발생률을 높이는 것으로 보고되었다 $(20,21)$. 최근에는 특정한 세균이 직장암을 유발하는 것이 아 니라 장내 세균 군집의 교란 (dysbiosis)이 CRC 발생과 진행에 관련이 있는 것으로 보고되고 있다 $(22,23)$. 장내 마이크로바이옴 에 의한 $\mathrm{CRC}$ 의 발생과 진행을 설명하는 가설로 운전자-탑승자 (driver-passenger) 모델이 제시되었다 (24). 이것은 여러 병원성 세균이 장점막과 연쇄적인 상호작용을 하면서 $\mathrm{CRC}$ 가 발생된다는 가설이다. $\mathrm{CRC}$ 의 발생에 B. fragilis가 운전자인 핵심 세균 (keystone pathogen)으로 추정되고 있으며, 이 세균에서 생성된 장독소가 주변 조직에 Th17 (Thelper type 17) 세포를 불러들여 조직에 염증을 유발하고 $\mathrm{CRC}$ 의 발생을 유도한다고 보고되었다 (25). 이후 장 조직의 염증 부위에서 Fusobacterium spp. 와 Streptococcus spp.와 같은 탑승자 세균이 증가함에 따라 CRC의 진행이 유도되는 것으로 추정되고 있다 (24). 이러한 여러 종의 세균에 의한 $\mathrm{CRC}$ 의 발생과 진행은 암 조직에 직접 접한 생물막 (biofilm) 안에서 일어나는 일로 추정되고 있다 (26). 따라서 $\mathrm{CRC}$ 와 관련한 장내 세균에 대한 연구를 위해서는 직장암 환자의 대변 검체에서 얻어진 세균 군집 정보 보다는 직장암 조직의 생 검 검체로부터 직접 얻어진 세균 군집 정보가 분석에 더욱 적합하다고 할 수 있다.

장내 세균은 직장암 상피의 염증, 적응 면역, 대사 기능에 영향을 줌으로써 항암치료의 반응에도 관여하는 것으로 보고되었다 $(8,27)$. 그러나 직장암에서 CRT에 의한 장내 마이크로바이옴의 변화에 대해서는 아직까지 많은 연구가 진행되지 않았다. 기존의 연구 결과는 동물 모델로부터 얻어졌거나 $(28,29)$, 인간 대상 연구이지만 주로 자궁경부암 등의 부인과 종양에서 방사선 치료 후 대변 검체를 통해 확인한 장내 마이크로바이옴의 변화에 국한되어 있다 (30-32). 대변 검체에서 확인되는 마이크로바이옴과 직장 암 조직 주변의 마이크로바이옴의 구성이 매우 다르다는 것이 이미 잘 알려져 있고 $(33,34)$, 직장암의 CRT 과정에서 방사선은 부인과 종양과는 다른 장기를 표적으로 하여 조사된다는 점, 직장암에서 암 조직과 접하고 있는 세균이 생물막 내에서 직장암의 발생과 진행에 관여하고 있는 점에도 불구하고 인간에서 직장암의 방사선 치료 전후의 마이크로바이옴의 변화를 조직 생검을 통 해 확인한 연구는 아직까지 없었다. 이 연구에서는 방사선 치료 전후의 인간 직장 선암 생검 검체로부터 얻어진 RNA 염기 서열 분석 자료에서 마이크로바이옴 정보를 추출하여 세균 군집의 변화를 분석하였으며 지금까지 보고된 적이 없는 여러가지 새로운 결과를 확인했다.

먼저 CRT 전후의 마이크로바이옴의 변화를 군집 전체의 관점에서 확인했을 때 두가지 새로운 결과를 확인할 수 있었다. 첫번째는 RNA 염기 서열 분석 자료에서 원시 reads 수에 대한 미생물의 표지 유전자에 정렬된 reads 수의 백분율이 CRT 여부와 무관하 게 개인안에서 유사하게 확인되었다는 것이다 (Table 2의 PathSeq mapped 열). 이것은 직장암에서 치료적 용량의 방사선 조사가 암 조직에 유전 독성 (genotoxic)을 가함에도 불구하고 방사선 조사된 암 조직이 염기 서열을 분석하는데 문제가 없다는 것을 의 미한다. 두번째로 확인된 결과는 Fig. 1 의 오른쪽 막대 도표와 Fig. 2의 주성분분석에서 확인된 것처럼 CRT 전과 후의 세균 군집 의 차이보다 개인 간의 세균 군집의 구성의 차이가 더 커서 CRT 전후로 세균 군집의 변화가 그리 크지 않은 것처럼 보인다는 것 이다. 이것은 방사선 조사에 의해 장내 미생물 군집이 변화한다는 기존의 연구결과와 다른 새로운 결과이다 (29). 기존의 연구에 서는 동일인 또는 동일한 동물 개체내에서 방사선 전과 후의 조직 검체를 반복적으로 획득하여 미생물 군집의 변화에 확인한 적 이 없었기 때문에 이 연구와 다른 결과가 나온 것으로 추측된다. 방사선 조사에 의해 장내 미생물이 변화하는 것이 이미 여러 보 고에서 확인되었으며 $(28,29)$ 시험관 내에서 다른 종의 세균이 각기 다른 방사선 감수성을 갖는다는 사실 $(35)$ 에 근거할 때 이러 한 CRT 전후 개체내의 근소한 마이크로바이옴의 변화는 장내 미생물의 빠른 항상성 회복 때문일 것으로 추측된다. 항생제 사용이 나 수술 전 제균 목적의 장 세척 후에 장내 마이크로바이옴의 구성이 이전의 상태로 빠르게 회복된다는 것이 보고되어 있다 $(36,37)$. 이 연구에서는 마지막 CRT 후 6-8주간의 간격 이후에 검체가 획득되었으므로 CRT 후 검체 획득까지 마이크로바이옴이 CRT 전의 상태로 회복될 수 있는 충분한 시간이 있었을 것으로 생각된다. 항생제 사용이나 장 세척이 장 전체의 미생물에 영향을 주는 것과 달리 치료 목적의 방사선 조사는 암 조직 주변에만 국한되므로 마이크로바이옴 구성의 회복은 더 빠르게 일어났을 것 으로 추측할 수 있다. 이 연구 결과에서 우리는 동일 개체내에서 CRT 전후 마이크로바이옴 비교를 위해서는 CRT 이후 단기간 내 에 검체 획득이 이루어 져야 한다는 결론과 조직 검체로부터 미생물 군집의 CRT 전후 변화를 코호트 간에 비교 분석하기 위해서 는 연구 계획 단계에서 개체 간의 미생물 군집의 차이를 극복할 만큼 많은 검체의 수를 필요로 한다는 결론을 도출할 수 있었다.

다음으로 개별 세균 단위에서 CRT 전의 세균 군집의 구성 분석에서는 문 단위에서 Proteobacteria, Bacteroidetes, Firmicutes, Actinobacteria 등이 가장 많은 비율을 차지고 있어 (Fig 1a. skyline 도표) 기존의 보고와 일치했다 $(28,38)$. 그러나 문 수준 분 석에서 방사선 조사에 의해 장내 미생물 중 Proteobacteria, Bacteroidetes의 증가, Firmicutes의 감소가 보고 되어있으나 이 연구 의 결과와 다소 불일치했다 (Fig. 1a). 기존의 보고와의 불일치는 기존의 연구가 인간이 아닌 쥐 등의 실험 동물로부터 결과를 얻 었거나 $(28,29)$ 대변 검체를 분석한 결과 $(30)$ 이기 때문으로 판단된다. 문 단위의 분석에서 CRT 전후로 가장 눈에 띄게 변화한 세균은 Fusobacteria로 CRT 이후 그 비율이 줄어들었다 (Fig. 1A, skyline 도표). 직장암에서 CRT에 의한 Fusobacteria의 감소는 
이 연구에서 최초로 보고된 것이지만 Fusobacteria가 직장암의 발생과 진행에 미치는 영향은 다수 보고되었다. 인간의 정상 대장 점막과 직장암 환자의 암 조직 점막의 미생물 군집 비교에서 암 조직에서 Fusobacteria가 유의하게 많은 것이 PCR, 165 rRNA, whole genome shot gun sequencing 및 조직 FISH 등 여러가지 방법으로 이미 확인되었다 $(39,40)$. 또한 앞서 언급된 것처럼 Fusobacteria는 탑승자 세균으로 직장암의 진행에 관여하고 있으며 그 외에도 Fusobacteria가 FadA adhesin에 의한 E-cadherin/ $\beta$-catenin 신호 전달의 조절 또는 T세포 매개 적응 면역의 저하를 통해 직장암 발생에 관여하고 있다는 것이 알려져 있다 $(26,41,42)$. 그러므로 직장암에서 CRT에 의한 Fusobacteria의 감소는 방사선 조사에 의한 미생물 군집의 변화가 직장암의 질병 경과에 영향을 미칠 수 있음을 의미한다.

개별 세균 단위에서 확인된 CRT 전후의 또 다른 변화는 ANCOM으로 확인된 CRT 후의 Prevotellaceae과의 감소였다 (Fig. 1d, Fig. 3a). 이전에 방사선 조사를 받은 생쥐의 정상 대장 점막에서 Prevotella가 감소한다는 보고가 있었지만 (28) 아직까지 직장암 점막에서는 보고된 바가 없다. 앞서 기술한 것처럼 직장암의 발생 초기에 운전자 세균에 의해 Th17 세포가 암 조직으로 모여들게 된다. 직장암 점막에서 증가된 Bacteroides와 Prevotella가 암 조직의 Th17 세포의 증가와 연관이 있었다는 보고에도 불구하고 (43) 직장암 발생, 진행에서의 Prevotella의 역할에 대해서는 Bacteroides 만큼 연구되지 않았다. IL-17 반응성 세포는 직장암의 진행 (44)과 예후 (45)에 결정적인 역할을 하고 있는 것으로 밝혀져, IL-17은 직장암의 항암면역 치료의 주요 표적으로 주목받고 있다 (46). 그러므로 아직까지 직장암에서 치료적 방사선 조사 자체가 암 조직 내의 Th17 세포의 변화에 어떠한 영향을 주는지 밝혀진 바가 없음에도 불구하고 CRT 후 직장암 점막에서의 Prevotella 감소는 CRT가 직장암의 항암면역치료의 효과에 영향을 줄 수 있다는 가능성을 보여준다. Fig. 3b에서 확인된 것처럼 직장암 점막에서 CRT 전후의 Prevotellaceae과의 변화는 CRT에 의한 직장암 점막 조직의 인간 유전자 발현 양상과 유의한 연관을 보여주고 있기 때문에 직장암에서 CRT는 단지 인간 암 조직의 유전 체를 치료 표적으로 하는 것이 아니라 암 조직 점막의 마이크로바이옴을 변화시킬 수 있으며, 마이크로바이옴과 인간 유전체와의 상호작용 통하여 종양-면역 미세환경에 영향을 미칠 가능성을 가지고 있다.

대장암 환자에서 마이크로바이옴에 대한 기존 연구의 대부분은 대장암 치료 전에 획득된 대변 또는 생검 검체의 마이크로바이옴 을 이용하여 대장암을 조기에 진단하거나 치료에 대한 반응 또는 예후를 예측하는 하는 방법을 확립하는 것을 목표로 했다. 그러 나 지금까지 보고된 연구들은 장내 미생물이 가진 고도의 다양성, 개인 간의 마이크로바이옴의 큰 차이를 극복할만큼 충분한 수 의 연구 대상자가 포함되지 않았었기 때문에 연구 결과 간의 재현성이 없었다. 이 연구의 분석 대상인 개인 안에서의 마이크로바 이옴의 동적 (dynamic) 변화는 기존 연구의 분석 대상인 개인 간의 정적인 (static) 마이크로바이옴의 차이에 비해 차원 (dimension)이 축소된 자료이기 때문에 미생물의 다양성, 개인 간의 차이를 더 잘 통제할 수 있는 설명 변수로 생각된다. 그러나 아직까지 대장암에서 장내 미생물의 동적 변화를 설명 변수로 하여 진단 또는 예후에 대한 표지자를 찾거나 예측 모형을 만든 연 구는 보고된 바가 없다. 이 연구에서는 전체 분석 대상자 11명 중 9명이 CRT에 반응하지 않은 환자였으며, 단지 2명만이 CRT에 반응한 환자로 CRT 반응 여부로 나눈 두 군에 포함된 대상자 수의 차이가 크기 때문에 마이크로바이옴 변화와 CRT 반응 여부 간의 통계분석은 실시할 수가 없었고 (Table 1), CRT에 반응한 환자와 반응하지 않은 환자 간의 마이크로바이옴의 변화에서 눈에 띄는 차이를 Fig. 1에서 발견할 수 없었기 때문에 CRT 전후의 마이크로바이옴의 변화와 대장암의 CRT 반응에 대한 연관분석을 실시할 수 없었다. 그럼에도 불구하고 대장암의 조기 진단, 치료 반응과 예후의 예측을 위해 마이크로바이옴의 변화를 분석하는 방법은 기존의 연구 결과 보다 더 나은 재현성을 보여줄 것으로 기대된다. 이 연구는 직장암 환자의 암 점막 조직을 CRT 전후로 동일인으로부터 반복적으로 획득하여 RNA 염기 서열 분석을 통해 마이크로바이옴의 변화를 확인하였다. 다만 마이크로바이옴 연 구의 전통적인 분석 대상인 $16 \mathrm{~S} r \mathrm{RNA}$ 를 분석한 것이 아니라 인체 조직과 세균으로부터 유래한 mRNA를 염기 서열 분석 대상으 로 삼았기 때문에 분석 reads 수가 기존의 방법에 비해 적고 분석 reads 수를 검체별로 표준화할 수 없다는 문제점으로 인해 마 이크로바이옴의 다양성에 대해서는 분석할 수 없는 한계가 있었다. 그럼에도 불구하고 mRNA 분석을 통해 미생물이 존재하고 있 는 직장암의 점막의 유전체 정보를 동시에 획득할 수 있어서 마이크로바이옴의 구성과 인간의 전사체를 통합하여 분석함으로써 CRT에 따른 마이크로바이옴의 변화와 암 조직의 유전체 변화 간의 상관관계가 존재함을 확인할 수 있었다. 이 연구에 포함된 분 석 대상자 수는 11 명으로 기존의 직장암 환자의 마이크로바이옴 연구 또는 정상인에서 방사선 조사에 따른 장내 미생물의 변화 연구의 검체 수와 비슷한 수준이었다 (30-32). 다만 기존의 연구들과 다르게 동일인에서 CRT 전후의 검체를 반복적으로 획득하 여 쌍 (pairwise)으로 비교하였기 때문에 개체간 마이크로바이옴의 차이가 결과 분석에 미치는 영향을 줄일 수 있었다. 그럼에도 불구하고 연구대상자의 수가 충분하지 않았기 때문에 CRT 전후로 일어나는 마이크로바이옴의 변화와 CRT 치료 반응에 대한 관 련성을 분석할 수 없었다. 앞으로 연구에서 충분한 수의 연구대상자가 확보된다면 CRT에 반응을 보이는 대상자와 반응을 보이지 않는 대상자를 구분하여 마이크로바이옴의 변화를 분석하여 직장암 환자에서 CRT에 앞서 마이크로바이옴의 조성을 근거로 방사 선 치료반응을 예측할 수 있는 미생물 표지자를 개발하고 방사선 치료 효과를 높이기 위한 장내 미생물 활용의 근거 자료를 확보 할 수 있을 것이다. 또한, 복부의 방사선 조사에 의한 장 점막 미생물의 교란과 방사선에 의한 직장 염증 발생의 연관성 (29), 무 
균 생쥐에서 방사선에 치료 후 장염의 감소 (47) 등을 근거로 하여 직장암에서 CRT 후의 부작용을 예측 (48)하거나 치료 (49)하 는데 특정 미생물을 활용할 수 있는 가능성을 발견할 수 있을 것이다. 마지막으로 CRT로 인한 직장암 점막의 파괴가 점막 미생물 의 전이 (translocation)를 유발하고 결과적으로 선천 면역에 영향을 주거나 (50), LPS-TLR4에 의한 APC의 활성화로 유도된 적응 면역의 조절을 유발할 수 있으므로 (51) 궁극적으로 CRT가 항암 면역 치료의 효과를 높이는 병합치료로 활용될 수 있는 근거가 마련될 것이다 (52).

\section{Acknowledgements}

이 연구는 보건장학회 (Health Fellowship Foundation)와 한국연구재단 (No. 2014R1A5A2010008, 2017R1C1B5076880)의 지원으로 수행되었음. 이 연구는 인체자원단위은행 (계명대학교 동산병원 인체자원단위은행)에서 제공한 인체자원을 이용하여 수 행되었음.

\section{REFERENCES}

1) Swedish Rectal Cancer Trial. Improved survival with preoperative radiotherapy in resectable rectal cancer. N Engl J Med 1997:336:980-7.

2) Kapiteijn E, Marijnen CA, Nagtegaal ID, Putter H, Steup WH, Wiggers T, et al. Preoperative radiotherapy combined with total mesorectal excision for resectable rectal cancer. N Engl J Med 2001;345:638-46.

3) Bosset JF, Collette L, Calais G, Mineur L, Maingon P, Radosevic-Jelic L, et al. Chemotherapy with preoperative radiotherapy in rectal cancer. N Engl J Med 2006;355:1114-23.

4) Han YD, Kim WR, Park SW, Cho MS, Hur H, Min BS, et al. Predictors of Pathologic Complete Response in Rectal Cancer Patients Undergoing Total Mesorectal Excision After Preoperative Chemoradiation. Medicine (Baltimore) 2015;94:e1971.

5) Demaria S, Ng B, Devitt ML, Babb JS, Kawashima N, Liebes L, et al. Ionizing radiation inhibition of distant untreated tumors (abscopal effect) is immune mediated. Int J Radiat Oncol Biol Phys 2004;58:862-70.

6) Vatner RE, Cooper BT, Vanpouille-Box C, Demaria S, Formenti SC. Combinations of immunotherapy and radiation in cancer therapy. Front Oncol 2014;4:325.

7) Tuyaerts S, Van Nuffel AMT, Naert E, Van Dam PA, Vuylsteke P, De Caluwé A, et al. PRIMMO study protocol: a phase II study combining PD-1 blockade, radiation and immunomodulation to tackle cervical and uterine cancer. BMC Cancer 2019;19:506.

8) Roy S, Trinchieri G. Microbiota: a key orchestrator of cancer therapy. Nat Rev Cancer 2017;17:271-85

9) lida N, Dzutsev A, Stewart CA, Smith L, Bouladoux N, Weingarten RA, et al. Commensal bacteria control cancer response to therapy by modulating the tumor microenvironment. Science 2013;342:967-70.

10) Sivan A, Corrales L, Hubert N, Williams JB, Aquino-Michaels K, Earley ZM, et al. Commensal Bifidobacterium promotes antitumor immunity and facilitates anti-PD-L1 efficacy. Science 2015;350:1084-9.

11) Bolger AM, Lohse M, Usadel B. Trimmomatic: a flexible trimmer for Illumina sequence data. Bioinformatics 2014;30: 2114-20. 
12) Dobin A, Davis CA, Schlesinger F, Drenkow J, Zaleski C, Jha S, et al. STAR: ultrafast universal RNA-seq aligner. Bioinformatics 2013;29:15-21.

13) Kostic AD, Ojesina Al, Pedamallu CS, Jung J, Verhaak RG, Getz G, et al. PathSeq: software to identify or discover microbes by deep sequencing of human tissue. Nat Biotechnol 2011:29:393-6.

14) Mandal S, Van Treuren W, White RA, Eggesbo M, Knight R, Peddada SD. Analysis of composition of microbiomes: a novel method for studying microbial composition. Microb Ecol Health Dis 2015;26:27663.

15) Love MI, Huber W, Anders S. Moderated estimation of fold change and dispersion for RNA-seq data with DESeq2. Genome Biol 2014;15:550.

16) Huang da W, Sherman BT, Lempicki RA. Systematic and integrative analysis of large gene lists using DAVID bioinformatics resources. Nat Protoc 2009;4:44-57.

17) Team RC, R: A language and environment for statistical computing. Vienna, Austria: R Foundation for Statstical Computing, 2018.

18) Wickham H, Ggplot2: elegant graphics for data analysis. New York : Springer-Verlag, 2016.

19) Dove WF, Clipson L, Gould KA, Luongo C, Marshall DJ, Moser AR, et al. Intestinal neoplasia in the ApcMin mouse: independence from the microbial and natural killer (beige locus) status. Cancer Res 1997;57:812-4.

20) Cuevas-Ramos G, Petit CR, Marcq I, Boury M, Oswald E, Nougayrède JP. Escherichia coli induces DNA damage in vivo and triggers genomic instability in mammalian cells. Proc Natl Acad Sci U S A 2010;107:11537-42.

21) Toprak NU, Yagci A, Gulluoglu BM, Akin ML, Demirkalem P, Celenk T, et al. A possible role of Bacteroides fragilis enterotoxin in the aetiology of colorectal cancer. Clin Microbiol Infect 2006:12:782-6.

22) Gao Z, Guo B, Gao R, Zhu Q, Qin H. Microbiota disbiosis is associated with colorectal cancer. Front Microbiol 2015; 6:20.

23) Wu N, Yang $X$, Zhang R, Li J, Xiao X, Hu Y, et al. Dysbiosis signature of fecal microbiota in colorectal cancer patients. Microb Ecol 2013:66:462-70.

24) Tjalsma H, Boleij A, Marchesi JR, Dutilh BE. A bacterial driver-passenger model for colorectal cancer: beyond the usual suspects. Nat Rev Microbiol 2012;10:575-82.

25) Hajishengallis G, Darveau RP, Curtis MA. The keystone-pathogen hypothesis. Nat Rev Microbiol 2012;10:717-25.

26) Li S, Konstantinov SR, Smits R, Peppelenbosch MP. Bacterial Biofilms in Colorectal Cancer Initiation and Progression. Trends Mol Med 2017;23:18-30.

27) Vétizou M, Pitt JM, Daillère $R$, Lepage $P$, Waldschmitt N, Flament $C$, et al. Anticancer immunotherapy by CTLA-4 blockade relies on the gut microbiota. Science 2015;350:1079-84.

28) Kim YS, Kim J, Park SJ. High-throughput 16S rRNA gene sequencing reveals alterations of mouse intestinal microbiota after radiotherapy. Anaerobe 2015:33:1-7. 
29) Gerassy-Vainberg S, Blatt A, Danin-Poleg Y, Gershovich K, Sabo E, Nevelsky A, et al. Radiation induces proinflammatory dysbiosis: transmission of inflammatory susceptibility by host cytokine induction. Gut 2018;67:97-107.

30) Wang A, Ling Z, Yang Z, Kiela PR, Wang T, Wang C, et al. Gut microbial dysbiosis may predict diarrhea and fatigue in patients undergoing pelvic cancer radiotherapy: a pilot study. PLoS One 2015;10:e0126312.

31) Nam YD, Kim HJ, Seo JG, Kang SW, Bae JW. Impact of pelvic radiotherapy on gut microbiota of gynecological cancer patients revealed by massive pyrosequencing. PLoS One 2013;8:e82659.

32) Manichanh C, Varela E, Martinez C, Antolin M, Llopis M, Doré J, et al. The gut microbiota predispose to the pathophysiology of acute postradiotherapy diarrhea. Am J Gastroenterol 2008;103:1754-61.

33) Flemer B, Lynch DB, Brown JM, Jeffery IB, Ryan FJ, Claesson MJ, et al. Tumour-associated and non-tumour-associated microbiota in colorectal cancer. Gut 2017;66:633-43.

34) Zoetendal EG, von Wright A, Vilpponen-Salmela T, Ben-Amor K, Akkermans AD, de Vos WM. Mucosa-associated bacteriain the human gastrointestinal tract are uniformly distributed along the colon and differ from the community recovered from feces. Appl Environ Microbiol 2002;68:3401-7.

35) Ranawat $P$, Rawat $S$. Radiation resistance in thermophiles: mechanisms and applications. World J Microbiol Biotechnol 2017;33:112.

36) Palleja A, Mikkelsen KH, Forslund SK, Kashani A, Allin KH, Nielsen T, et al. Recovery of gut microbiota of healthy adults following antibiotic exposure. Nat Microbiol 2018;3:1255-65.

37) Jalanka J, Salonen A, Salojärvi J, Ritari J, Immonen O, Marciani L, et al. Effects of bowel cleansing on the intestinal microbiota. Gut 2015:64:1562-8.

38) Sinha R, Ahn J, Sampson JN, Shi J, Yu G, Xiong X, et al. Fecal Microbiota, Fecal Metabolome, and Colorectal Cancer Interrelations. PLoS One 2016;11:e0152126.

39) Xu K, Jiang B. Analysis of Mucosa-Associated Microbiota in Colorectal Cancer. Med Sci Monit 2017;23:4422-30.

40) Vogtmann E, Hua X, Zeller G, Sunagawa S, Voigt AY, Hercog R, et al. Colorectal Cancer and the Human Gut Microbiome: Reproducibility with Whole-Genome Shotgun Sequencing. PLoS One 2016;11:e0155362.

41) Rubinstein MR, Wang X, Liu W, Hao Y, Cai G, Han YW. Fusobacterium nucleatum promotes colorectal carcinogenesis by modulating E-cadherin/beta-catenin signaling via its FadA adhesin. Cell Host Microbe 2013;14:195-206.

42) Mima K, Sukawa $Y$, Nishihara R, Qian ZR, Yamauchi M, Inamura K, et al. Fusobacterium nucleatum and $T$ Cells in Colorectal Carcinoma. JAMA Oncol 2015:1:653-61.

43) Sobhani I, Tap J, Roudot-Thoraval F, Roperch JP, Letulle S, Langella P, et al. Microbial dysbiosis in colorectal cancer (CRC) patients. PLoS One 2011;6:e16393.

44) Wu D, Wu P, Huang Q, Liu Y, Ye J, Huang J. Interleukin-17: a promoter in colorectal cancer progression. Clin Dev Immunol 2013;2013:436307. 
45) Liu J, Duan $Y$, Cheng $X$, Chen $X$, Xie $W$, Long $H$, et al. IL-17 is associated with poor prognosis and promotes angiogenesis via stimulating VEGF production of cancer cells in colorectal carcinoma. Biochem Biophys Res Commun 2011:407:348-54.

46) Wang K. Targeting IL-17 for cancer-associated inflammation and immunity. J Immunol 2017;198:66.5.

47) Crawford PA, Gordon Jl. Microbial regulation of intestinal radiosensitivity. Proc Natl Acad Sci U S A 2005;102:13254-9.

48) Ferreira MR, Muls A, Dearnaley DP, Andreyev HJ. Microbiota and radiation-induced bowel toxicity: lessons from inflammatory bowel disease for the radiation oncologist. Lancet Oncol 2014;15:e139-47.

49) Cui M, Xiao H, Li Y, Zhou L, Zhao S, Luo D, et al. Faecal microbiota transplantation protects against radiation-induced toxicity. EMBO Mol Med 2017:9:448-61.

50) Nejdfors $P$, Ekelund M, Weström BR, Willén R, Jeppsson B. Intestinal permeability in humans is increased after radiation therapy. Dis Colon Rectum 2000;43:1582-1587; discussion 1587-8.

51) Paulos CM, Wrzesinski C, Kaiser A, Hinrichs CS, Chieppa M, Cassard L, et al. Microbial translocation augments the function of adoptively transferred self/tumor-specific CD8+ T cells via TLR4 signaling. J Clin Invest 2007;117:2197-204.

52) Goubet AG, Daillère R, Routy B, Derosa L, M Roberti P, Zitvogel L. The impact of the intestinal microbiota in therapeutic responses against cancer. C R Biol 2018;341:284-9. 